\title{
Induction of neutralizing antibodies against tier 2 human immunodeficiency virus 1 in rhesus macaques infected with tier 1B simian/human immunodeficiency virus
}

\author{
Ai Himeno ${ }^{1} \cdot$ Yuki Ishida $^{1} \cdot$ Hiromi Mori ${ }^{1} \cdot$ Kanako Matsuura $^{1} \cdot$ Minako Kikukawa $^{1} \cdot$ Hiromi Sakawaki $^{1}$. \\ Tomoyuki Miura' ${ }^{1}$ (D)
}

Received: 7 September 2018 / Accepted: 17 January 2019 / Published online: 28 February 2019

(C) The Author(s) 2019

\begin{abstract}
We previously developed CCR5-tropic neutralization-resistant simian/human immunodeficiency virus (SHIV) strains and a rhesus macaque model of infection with these SHIVs. We induced the production of neutralizing antibodies (nAbs) against HIV-1 by infecting rhesus macaques with different neutralization-resistant SHIV strains. First, SHIV-MK1 (MK1) (neutralization susceptible, tier 1B) with CCR5 tropism was generated from SHIV-KS661 using CXCR4 as the main co-receptor. nAbs against parental-lineage and heterologous tier 2 viruses were induced by tier 1B virus (MK1) infection of the rhesus macaque MM482. We analyzed viral resistance to neutralization over time in MM482 and observed that the infecting virus mutated from tier 1B to tier 2 at 36 weeks postinfection (wpi). In addition, an analysis of mutations showed that N169D, K187E, S190N, S239, T459N (T459D at 91 wpi), and V842A mutations were present after 36 wpi. This led to the appearance of neutralization-resistant viral clones. In addition, MK1 was passaged in three rhesus macaques to generate neutralizationresistant SHIV-MK38 (MK38) (tier 2). We evaluated nAb production by rhesus macaques infected with SHIV-MK38 \#818 (\#818) (tier 2), a molecular clone of MK38. Neutralization of the parental lineage was induced earlier than in macaques infected with tier 1B virus, and neutralization activity against heterologous tier 2 virus was beginning to develop. Therefore, CCR5-tropic neutralization-resistant SHIV-infected rhesus macaques may be useful models of anti-HIV-1 nAb production and will facilitate the development of a vaccine that elicits nAbs against HIV-1.
\end{abstract}

\section{Introduction}

Antiretroviral agents are used against human immunodeficiency virus type 1 (HIV-1), but eliminating latent HIV-1 is difficult [1-9]. Therefore, suppression and prevention of HIV-1 infection by passive administration of neutralizing antibodies (nAbs) and induction of $\mathrm{nAbs}$ by vaccination would be beneficial [10-17]. Few HIV-1-infected patients

Handling Editor: Li Wu.

Electronic supplementary material The online version of this article (https://doi.org/10.1007/s00705-019-04173-5) contains supplementary material, which is available to authorized users.

Tomoyuki Miura

tmiura@infront.kyoto-u.ac.jp

1 Laboratory of Primate Model, Research Center for Infectious Diseases, Institute for Frontier Life and Medical Science, Kyoto University, 53 Shogoin kawahara-cho, Sakyo-ku, Kyoto 606-8507, Japan
(10-30\%) produce nAbs, and about $1 \%$ of infected people generate highly potent $n A b s$ with broad neutralization coverage of HIV (elite neutralizers) [18, 19]. Due to advances in antigen-specific B-cell isolation techniques, broadly neutralizing monoclonal antibodies have been isolated from HIV1-infected patients [20-23]. Passive administration of these nAbs was protective against simian/human immunodeficiency virus (SHIV) in a macaque model [24-30]. However, inducing potent and broadly reactive $\mathrm{nAbs}$ by vaccination is problematic. Although the production of potent nAbs with broad cross-reactivity is related to somatic hypermutation [31-34], the mechanism of induction is unknown. An animal model in which nAbs are produced would facilitate clarification of the mechanism of induction of nAbs against HIV-1, as well as the development of effective vaccines.

The rhesus macaque model of simian immunodeficiency virus (SIV) infection is important as an animal model of AIDS for pathogenicity studies and vaccine development. However, the envelope protein (Env) of SIV has a low level of amino acid sequence similarity to that of HIV-1 
[35], and nAbs against the two viruses are not cross-reactive [36]. By contrast, SHIV [37], which is SIV containing the env gene of HIV-1, can be used to evaluate nAbs against the Env protein of HIV-1.

Controlling HIV and SIV is difficult, as they use CCR5 as a co-receptor; however, SHIV-89.6P (CXCR4) is easy to control [38]. Seaman et al. [39] reported that clustering analysis of the patterns of sensitivity defined four subgroups of clinical HIV-1 strains: those having very high (tier 1A), above-average (tier 1B), moderate (tier 2), or low (tier 3) sensitivity to antibody-mediated neutralization, with the majority of viruses belonging to tier 2. Indeed, the production of antibodies in rhesus macaques suppressed replication of SHIV-KS661(KS661) (CXCR4tropic, tier 1B) [40]. SHIV-SF162P3 and SHIV-AD8 (tier 2) are used as challenge viruses in vaccine development $[33,41-46]$. We generated several different tier 2 challenge SHIVs to increase the reliability of the research. SHIV-89.6 is frequently used in vaccine studies [47-50] and thus was selected for this study. First, KS661 (SHIV89.6 strain), which mainly uses CXCR4 as a co-receptor, was modified to produce SHIV-MK1 (MK1) (tier 1B) and inoculated into rhesus macaques. Next, viruses from the infected macaques were passaged in two macaques, resulting in neutralization-resistant SHIV-MK38 (MK38) (tier 2) [51]. Ishida et al. [52] produced the MK38 molecular clone SHIV-MK38 \#818 (\#818) (tier 2).

In this study, we evaluated $\mathrm{nAb}$ production by rhesus macaques infected with CCR5-tropic tier 1 and tier 2 SHIV. nAbs against tier 2 virus were induced by tier 1B virus infection, and production of nAbs against tier 2 virus began earlier in Tier 2 virus infection. Our findings provide important insights that might be applicable to HIV-1 vaccine development.

\section{Materials and methods}

\section{Cell culture}

HEK293T (293T) cells were cultured in Dulbecco's modified Eagle's medium (DMEM) (Fujifilm Wako Pure Chemical Corporation, Osaka, Japan) supplemented with $10 \%$ (vol/ vol) heat-inactivated fetal bovine serum (FBS; JR Scientific Inc., Woodland, CA, USA). TZM-bl cells were cultured in DMEM supplemented with $10 \%$ (vol/vol) heat-inactivated FBS, 2 mM sodium pyruvate (MP Biomedicals Inc., Santa Ana, CA, USA) and $4 \mathrm{mM}$ L-glutamine (Fujifilm Wako Pure Chemical Corporation). Cells were harvested and passaged using trypsin/ethylenediaminetetraacetic acid solution (Nacalai Tesque, Kyoto, Japan) and were maintained at $37{ }^{\circ} \mathrm{C}$ in a humidified atmosphere containing $5 \% \mathrm{CO}_{2}$.

\section{Viruses and animal experiments}

SHIV-MK1, SHIV-MK1-first passage, SHIV-MK1second passage, and SHIV-MK38 were described previously [51], as was SHIV-MK38\#818 [52]. Based on the sequence information about co-receptor tropism of HIV-1 $[53,54]$, we designed neutralization-susceptible CCR5tropic (tier 1B) MK1 by introducing five amino acid mutations (E305K, R306S, R318T, R319G, and N320D). We inoculated MK1 intravenously into two rhesus macaques (MM482 and MM483). To allow MK1 to adapt, we conducted in vivo passages from macaque M482 to macaque MM498 (SHIV-MK1-first passage), and subsequently to macaque MM504 (SHIV-MK1-second passage). This enhanced viral replication and the re-isolated virus was designated SHIV-MK38 (MK38). Next, we inoculated MK38 intravenously into rhesus macaques (MM481, MM501, and MM502) [51]. The molecular clone SHIVMK38\#818 (\#818) (tier 2) was produced by Ishida et al. [52]. We mimicked the infection route of HIV-1 to humans and inoculated \#818 into the rectum of rhesus macaques (MM 596, MM 597, and MM 599; Table 1) [52]. R5 virus infects intestinal memory CD4-positive T cells [55, 56]. Indian-origin rhesus macaques were used in accordance with the institutional regulations of the Committee for Experimental Use of Non-human Primates of the Institute for Frontier Life and Medical Sciences, Kyoto University, Kyoto, Japan. Macaques were housed in a biosafety level 3 facility and all procedures were performed in this facility.

\section{Pseudotype viruses}

Pseudotype viruses harboring the env gene of MK1, \#818, murine leukemia virus (MLV), or clade B panel viruses (NIH AIDS reagent program) were prepared by co-transfecting $293 \mathrm{~T}$ cells with $\mathrm{pSG} \Delta \mathrm{env}$ and pcDNA3.1 vectors expressing the respective env genes. We obtained pSG $\Delta$ env, pcDNA3.1 vectors expressing clade B env, and vectors expressing MLV env from the NIH AIDS reagent program. To construct the pcDNA3.1 vector expressing the rev and env genes of MK1 and \#818, approximately 3.0 $\mathrm{kb}$ of the region including the rev and env genes of pMK1 [51] and pMK38\#818 [52] were amplified by PCR using the primers IFrevF (GCCTTAGGCATCTCCTAT) and SHenv7R (GGAGTATTCATATACTGTCCC). PCR was performed as follows: one cycle of denaturation $\left(94{ }^{\circ} \mathrm{C}\right.$ for $2 \mathrm{~min}), 30$ cycles of amplification $\left(98^{\circ} \mathrm{C}\right.$ for $10 \mathrm{~s}, 52{ }^{\circ} \mathrm{C}$ for $30 \mathrm{~s}$, and $68{ }^{\circ} \mathrm{C}$ for $\left.90 \mathrm{~s}\right)$ and a final extension $\left(68^{\circ} \mathrm{C}\right.$ for $10 \mathrm{~min}$ ) using KOD Plus Neo buffer, $0.2 \mathrm{mM}$ dNTPs, $15 \mu \mathrm{M}$ primers, $0.02 \mathrm{U}$ of KOD Plus NEO (Toyobo Co., Ltd, Osaka, Japan), and a template. Approximately $5.5 \mathrm{~kb}$ 
Table 1 Plasma analyzed for neutralization activity (Matsuda et al., 2010, Virology. Ishida et al., 2015, JGV)

\begin{tabular}{|c|c|c|c|c|c|c|c|}
\hline \multirow[t]{2}{*}{ Macaque ID } & \multicolumn{2}{|l|}{ Virus } & \multicolumn{4}{|c|}{ Infected pathology } & \multirow[t]{2}{*}{ Reference } \\
\hline & Strain & Tier & Methods & $\begin{array}{l}\text { Peak of Plasma } \\
\text { Viral Load (cop- } \\
\text { ies } / \mathrm{mL} \text { ) }\end{array}$ & $\begin{array}{l}\text { Set point of } \\
\text { Plasma Viral Load } \\
\text { (copies } / \mathrm{mL} \text { ) }\end{array}$ & $\begin{array}{l}\text { CD4 count in } \\
\text { Peripheral Blood }\end{array}$ & \\
\hline *MM482 & $\begin{array}{l}\text { MK1 (molecular } \\
\text { clone) }\end{array}$ & $1 \mathrm{~B}$ & $\begin{array}{l}\text { 20000TCID50/ } \\
\text { Intra Venous }\end{array}$ & $10^{7}-10^{8}$ & $10^{3}-10^{4}$ & $\begin{array}{l}\text { transiently } \\
\text { decreased and } \\
\text { recovered }\end{array}$ & $\begin{array}{l}\text { Matsuda et al., } \\
\text { 2010, Virology. }\end{array}$ \\
\hline MM483 & & & & $10^{6}$ & undetectable & Not Available & \\
\hline *MM498 & MK1-1stPassage & $1 \mathrm{~B}-2$ & Intra Venous & $10^{7}-10^{8}$ & $10^{4}$ & Not Available & \\
\hline *MM504 & MK1-2ndPassage & $1 \mathrm{~B}-2$ & Intra Venous & & $10^{5}-10^{6}$ & continuous reduc- & \\
\hline *MM481 & MK38 & 2 & 20000TCID50/ & & $10^{6}-10^{7}$ & tion without & \\
\hline *MM501 & & & Intra Venous & & $10^{4}$ & signs of recovery & \\
\hline *MM502 & & & & & $10^{5}$ & & \\
\hline $\begin{array}{l}\text { MM596 } \\
* \text { MM597 }\end{array}$ & $\begin{array}{l}\text { \#818 (molecular } \\
\text { clone) }\end{array}$ & & $\begin{array}{l}\text { 10000TCID50/ } \\
\text { Intra Rectal }\end{array}$ & & $\begin{array}{l}\text { undetectable } \\
10^{5}-10^{6}\end{array}$ & reduction & $\begin{array}{l}\text { Ishida et al., 2015, } \\
\text { JGV. }\end{array}$ \\
\hline MM599 & & & & & undetectable & & \\
\hline
\end{tabular}

* : Persistently infected macaque

of the $e n v$-deleted region from pcDNA3.1-SHIVMNA [57] (pcDNA3.1-SHIV-MNA env was generated by InFusion cloning using the pcDNA3.1 vector and SHIV-MNA env PCR product) was amplified by PCR using the primers SHenv7F (GGGACAGTATATGAATACTCC) and IFrevR (ATAGGAGATGCCTAAGGC). PCR was performed as follows: 1 cycle of denaturation $\left(94^{\circ} \mathrm{C}, 2 \mathrm{~min}\right), 30$ cycles of amplification $\left(98^{\circ} \mathrm{C}\right.$ for $10 \mathrm{~s}, 52^{\circ} \mathrm{C}$ for $30 \mathrm{~s}$, and $68^{\circ} \mathrm{C}$ for $3 \mathrm{~min})$, and a final extension $\left(68{ }^{\circ} \mathrm{C}, 10 \mathrm{~min}\right)$. The buffer and polymerase were as above. The PCR products were purified using a NucleoSpin Gel and PCR Cleanup Kit (TaKaRa Bio Inc., Shiga, Japan), and env-depleted pcDNA3.1 was reacted with the inserted env DNA. Cloning was conducted using an In-Fusion HD Cloning Kit (TaKaRa), and the resulting plasmid DNA was introduced into $\mathrm{Stb} 13$ cells by electroporation.

Pseudotype viruses harboring the env gene obtained from the plasma of MM482 at weekly intervals after infection were prepared by co-transfecting $293 \mathrm{~T}$ cells with $\mathrm{pSG} \Delta \mathrm{env}$ and pcDNA3.1 vectors expressing the respective env genes. We produced $\mathrm{pSG} \Delta \mathrm{env}$ in the same manner as above. Viral RNA was extracted from plasma using a QIAamp Viral RNA Mini Kit (QIAGEN, Hilden, Germany) according to the manufacturer's protocol. cDNA, including the env gene, was synthesized from the extracted RNA by reverse transcription using random hexamers (Invitrogen, Waltham, MA, USA) and SuperScript IV Reverse Transcriptase (Invitrogen). To construct the pcDNA3.1 vector expressing the rev and env genes of viruses obtained from MM482, at weekly intervals after infection, approximately $3.3 \mathrm{~kb}$ of the region including the rev and env genes in the cDNA template was amplified by PCR using the primers SHenv0F (AGAGCAAGAAATGGA GCCAG) and SHenv8.5R (CCATAGCCAGCCAAATGT
CT). PCR was performed as follows: 35 cycles of amplification $\left(98^{\circ} \mathrm{C}\right.$ for $10 \mathrm{~s}, 53{ }^{\circ} \mathrm{C}$ for $5 \mathrm{~s}$, and $68^{\circ} \mathrm{C}$ for $\left.15 \mathrm{~s}\right)$ using KOD One PCR Master Mix (Toyobo), $15 \mu \mathrm{M}$ primers, and template. Next, approximately $2.9 \mathrm{~kb}$ of the region including the rev and env genes in the PCR product was amplified by nested PCR using the primers InsertF3 (TTCACCGGC TTAGGCATCTCCTATGGCAGGAAGAAGCGGAGA) and InsertR3 (TTGACCACTTGCCCCCCATTTGTCCCT CACAAGAGAGTGAGCT). PCR was performed as above. The PCR products were purified using a NucleoSpin Gel and PCR Clean-up Kit (TaKaRa) and sequenced directly (Macrogen Japan Corp., Tokyo, Japan). Approximately $5.5 \mathrm{~kb}$ of the $e n v$-deleted region from pcDNA3.1-SC422661 (obtained from the National Institutes of Health [NIH, Bethesda, MD, USA] AIDS reagent program) were amplified by PCR using the primers VectorF3 (AATGGGGGGCAAGTGGTCAA) and VectorR3 (AGGAGATGCCTAAGCCGGTGAA). PCR was performed as follows: 35 cycles of amplification; $98^{\circ} \mathrm{C}$ for $10 \mathrm{~s}, 58{ }^{\circ} \mathrm{C}$ for $5 \mathrm{~s}$, and $68{ }^{\circ} \mathrm{C}$ for $27 \mathrm{~s}$. The buffer and polymerase were as above. The PCR products were purified, and $e n v$-depleted pcDNA3.1 was reacted with the inserted env DNA. Cloning was conducted using an NEBuilder HiFi DNA Assembly Master Mix (NEB Inc., Beverly, MA, USA), and the resulting plasmid DNA was introduced into Stbl3 cells by electroporation.

\section{Neutralization assays}

Neutralization assays were performed using various pseudoviruses with pooled plasma from HIV-1-infected patients (ZeptoMetrix, Buffalo, NY, USA) as a positive control. Luciferase activity was measured in TZM-bl cells [58]. Plasma was collected from the infected macaques 
$[51,52]$ and serially diluted, and the $50 \%$ inhibitory dilution of the plasma $\left(\mathrm{ID}_{50}\right)$ was determined with the infectivity of wells lacking plasma defined as $100 \%$. A high $\mathrm{ID}_{50}$ value thus indicates potent inhibition. Plasma from infected macaques was inactivated at $56^{\circ} \mathrm{C}$ for $60 \mathrm{~min}$ and centrifuged at $11,000 \mathrm{rpm}$ for $10 \mathrm{~min}$. The pooled plasma of HIV-1-infected individuals and infected macaques was diluted in fourfold steps from 1:50 to 1:204,800 and pre-incubated with virus $\left(100 \mathrm{TCID}_{50}\right)$ at $37{ }^{\circ} \mathrm{C}$ for 60 min. Next, 5,000 TZM-bl cells were cultured with the pre-incubated mixture in the presence of $5 \mathrm{mg}$ of DEAE dextran $/ \mathrm{mL}$ at $37{ }^{\circ} \mathrm{C}$ for $48 \mathrm{~h}$. To measure luciferase activity, 50 of $\mu \mathrm{L}$ cell lysate solution (Toyo B-Net, Tokyo, Japan) was added to each well and the plate was agitated for $15 \mathrm{~min}$. An aliquot of $30 \mu \mathrm{L}$ of lysate was transferred to a Nunc F96 MicroWell white plate (Thermo Fisher Scientific, Waltham, MA, USA), and the luminescent substrate $(50 \mu \mathrm{L})$ was added to each well. Luciferase activity was calculated with Mikrowin and a TriStar LB 941 reader (Berthold Technologies, Bad Wildbad, Germany). ID $_{50}$ values were calculated as described previously [39].

As an anti-HIV-1-neutralizing monoclonal antibody, we used KD-247 (which recognizes the epitope GPGR in the V3 region of gp120 and was kindly provided by the Chemo-Sero-Therapeutic Research Institute, Japan). KD-247 was diluted fourfold from 20 to $0.005 \mu \mathrm{g} / \mathrm{mL}$, and $\mathrm{IC}_{50}$ values were calculated as previously described [39].

\section{Results}

\section{Infection of macaques and antibody production}

In MM482 and MM483, the plasma viral RNA level peaked at $10^{6}-10^{8}$ copies $/ \mathrm{mL}$ and was maintained at $10^{3}-10^{4}$ copies/mL in MM482. In MM498, MM504, MM481, MM501, and MM502, the plasma viral RNA level peaked at $10^{7}-10^{8}$ copies $/ \mathrm{mL}$ and was maintained at $10^{4}-10^{7}$ copies $/ \mathrm{mL}$ in all of these macaques. In MM596, MM597, and MM599, the plasma viral RNA level peaked at $10^{7}-10^{8}$ copies $/ \mathrm{mL}$ and was maintained at $10^{5}-10^{6}$ copies/mL only in MM597. Seven of the ten rhesus macaques developed persistent infections. Many HIV-1-infected patients have a persistent infection with neutralization-resistant virus [39]. To develop a rhesus macaque model of anti-HIV-1 nAb production, we evaluated the neutralization activity and plasma of seven persistently SHIV-infected rhesus macaques (Table 1).

\section{Neutralization against env of parental-lineage virus}

Neutralization of parental-lineage virus was evaluated by luciferase assay using human pooled plasma (HPP) from HIV-1-infected patients as the positive control and a pseudovirus containing mouse leukemia virus (MLV) env as the negative control. Potent neutralization of MK1, equal to or higher than that of HPP ( $\left.\mathrm{ID}_{50}, 831\right)$, was detected in MM482, MM504, MM501, MM502, and MM597 (ID ${ }_{50}$, $10,200,1,337,2,679,831$, and 4,587, respectively). Additionally, neutralization activity against \#818 higher than that of HPP ( $\left.\mathrm{ID}_{50}, 287\right)$ was detected in MM504, MM501 and MM597 (ID $50,1,357,907$ and 474) (Table 2). These
Table 2 Neutralization activity against parental-lineage virus

\begin{tabular}{|c|c|c|c|c|c|}
\hline \multirow{2}{*}{$\begin{array}{l}\text { weeks post } \\
\text { inoculaton }\end{array}$} & \multirow{2}{*}{$\begin{array}{l}\text { Time Point } \\
\quad \text { (wpi) }\end{array}$} & \multirow{2}{*}{$\begin{array}{c}\text { Inoculated } \\
\text { Strain }\end{array}$} & MLV & MK1 & MK38\#818 \\
\hline & & & control & Tier1B & Tier2 \\
\hline MM482 & 135 & SHIV-MK1 & $<100$ & 10200 (3018) & $170(37)$ \\
\hline MM498 & 103 & SHIV-MK1-1stPS & $<100$ & $671(70)$ & 265 (12) \\
\hline MM504 & 103 & SHIV-MK1-2ndPS & $<100$ & 1337 (234) & 1357 (829) \\
\hline MM481 & 61 & \multirow{3}{*}{ SHIV-MK38 } & $<100$ & $602(51)$ & $230(25)$ \\
\hline MM501 & 60 & & $<100$ & 2679 (264) & 907 (47) \\
\hline MM502 & 61 & & $<100$ & $831(255)$ & $166(40)$ \\
\hline MM597 & 60 & SHIV-MK38\#818 & $<100$ & 4587 (503) & $474(167)$ \\
\hline \multicolumn{3}{|c|}{ HPP } & $<100$ & $831(261)$ & 287 (157) \\
\hline Range of ID & $100-119$ & $20-999 \geqq 1000$ & & & \\
\hline $\begin{array}{l}<100 \text { : unde } \\
\text { HPP : Huma } \\
\text { wpi : Weeks } \\
\text { (): Standar }\end{array}$ & $\begin{array}{l}00 \text { times dilutic } \\
\text { ool Plasma } \\
\text { sst Infection } \\
\text { eviation }\end{array}$ & & & & \\
\hline
\end{tabular}


Table 3 Neutralization activity and breadth against parental-lineage virus over time

\section{A. MM482: Infected with MK1}

\begin{tabular}{|c|c|c|c|}
\hline \multirow{2}{*}{$\begin{array}{c}\text { weeks post } \\
\text { inoculaton }\end{array}$} & MLV & MK1 & MK38\#818 \\
\cline { 2 - 4 } & control & Tier1B & Tier2 \\
\hline \hline pre & $<100$ & $<100$ & $<100$ \\
\hline 6 & N.D. & $16972(6637)$ & $<100$ \\
\hline 12 & N.D. & $20396(5544)$ & $<100$ \\
\hline 36 & N.D. & $15598(2933)$ & $<100$ \\
\hline 46 & N.D. & $16076(1744)$ & $<100$ \\
\hline 64 & N.D. & $10103(2694)$ & $226(29)$ \\
\hline 81 & N.D. & $10375(2381)$ & $108(15)$ \\
\hline 101 & N.D. & $13379(2836)$ & $293(37)$ \\
\hline 135 & $<100$ & $10199(3018)$ & $170(37)$ \\
\hline HPP & $<100$ & $831(261)$ & $287(157)$ \\
\hline
\end{tabular}

C. MM501: Infected with MK38

\begin{tabular}{|c|c|c|c|}
\hline \multirow{2}{*}{$\begin{array}{c}\text { weeks post } \\
\text { inoculaton }\end{array}$} & MLV & MK1 & MK38\#818 \\
\cline { 2 - 4 } & control & Tier1B & Tier2 \\
\hline \hline 1 & $<100$ & $<100$ & $<100$ \\
\hline 6 & N.D. & $<100$ & $<100$ \\
\hline 12 & N.D. & $1126(96)$ & $112(6)$ \\
\hline 27 & N.D. & $1540(142)$ & $977(86)$ \\
\hline 40 & N.D. & $1157(134)$ & $670(27)$ \\
\hline 52 & N.D. & $2330(108)$ & $859(48)$ \\
\hline 60 & $<100$ & $2679(264)$ & $907(47)$ \\
\hline HPP & $<100$ & $831(261)$ & $287(157)$ \\
\hline
\end{tabular}

Range of $I D_{50}: 100-119 \quad 120-999$

$<100$ : under 100 times dilution

N.D. : Not Done

HPP : Human Pool Plasma

wpi : Weeks Post Infection

( ) : Standard Deviation

results imply that $\mathrm{nAbs}$ against tier 2 virus are induced in macaques infected with tier 1B virus. Antibodies against MK1 were induced at 6 wpi in MM482 and at 12 wpi in MM501, MM504, and MM597 (Table 3). In contrast, antibodies against \#818 were induced at 64 wpi in MM482, 30 wpi in MM504, and at 12 wpi in MM501 and MM597 (Table 3). These results suggest that $n$ Abs against tier 2 virus are induced earlier in macaques infected with tier 2 virus than in those infected with tier 1B virus. Furthermore, the neutralization activity increased over time.

\section{Neutralization against the ENV protein of heterologous viruses}

To investigate the ability of the plasma of infected macaques to neutralize a broad spectrum of viruses, we evaluated

\section{B. MM504: Infected with MK1-2ndPS}

\begin{tabular}{|c|c|c|c|}
\hline \multirow{2}{*}{$\begin{array}{c}\text { weeks post } \\
\text { inoculaton }\end{array}$} & MLV & MK1 & MK38\#818 \\
\cline { 2 - 4 } & control & Tier1B & Tier2 \\
\hline \hline 1 & $<100$ & $<100$ & $<100$ \\
\hline 6 & N.D. & $<100$ & $<100$ \\
\hline 12 & N.D. & $359(95)$ & $<100$ \\
\hline 30 & N.D. & $1757(240)$ & $845(201)$ \\
\hline 50 & N.D. & $2127(367)$ & $629(77)$ \\
\hline 65 & N.D. & $1608(230)$ & $808(139)$ \\
\hline 85 & N.D. & $1265(177)$ & $676(245)$ \\
\hline 103 & $<100$ & $1337(234)$ & $1357(829)$ \\
\hline HPP & $<100$ & $831(261)$ & $287(157)$ \\
\hline
\end{tabular}

D. MM597: Infected with \#818

\begin{tabular}{|c|c|c|c|}
\hline \multirow{2}{*}{$\begin{array}{c}\text { weeks post } \\
\text { inoculaton }\end{array}$} & MLV & MK1 & MK38\#818 \\
\cline { 2 - 4 } & control & Tier1B & Tier2 \\
\hline \hline pre & $<100$ & $<100$ & $<100$ \\
\hline 6 & N.D. & $<100$ & $<100$ \\
\hline 12 & N.D. & $601(116)$ & $255(68)$ \\
\hline 28 & N.D. & $2647(170)$ & $696(118)$ \\
\hline 41 & N.D. & $2807(757)$ & $622(160)$ \\
\hline 51 & N.D. & $4432(669)$ & $500(100)$ \\
\hline 60 & $<100$ & $4587(503)$ & $474(167)$ \\
\hline HPP & $<100$ & $831(261)$ & $287(157)$ \\
\hline
\end{tabular}

neutralization activity against heterologous viruses. Potent neutralization of SF162, similar to that of HPP, was detected in all macaques (Table 4). In MM482 and MM597, the neutralization activity of 6535 was similar to that of HPP ( $\mathrm{ID}_{50}, 345$ and 192, respectively) (Table 4). In MM482 and MM597, the $\mathrm{ID}_{50}$ value against REJO4541 was 104 and 103, respectively (Table 4). These results suggest that MM482 and MM597 have broader neutralization activity than the other five macaques, although the neutralization activity of plasma from MM482 and MM597 against tier1B and tier2 viruses was less than that of HPP in all cases (Table 4). In MM482, antibodies against infectious strains and SF162 were induced at 6 wpi $\left(\mathrm{ID}_{50}, 755\right)$ (Table 5A). In MM597, antibodies against infectious strains were induced at $12 \mathrm{wpi}$ $\left(\mathrm{ID}_{50}, 255\right)$, and antibodies were induced against SF162 at 6 wpi $\left(\mathrm{ID}_{50}, 300\right)$ (Table $\left.5 \mathrm{~B}\right)$. In MM482, the $\mathrm{ID}_{50}$ value 
Table 4 Neutralization activity against heterologous viruses

\begin{tabular}{|c|c|c|c|c|c|c|}
\hline weeks post & Time Point & Inoculated & MLV & SF162 & 6535 & REJO4541 \\
\cline { 6 - 7 } inoculaton & (wpi) & Strain & control & Tier1A & Tier1B & Tier2 \\
\hline \hline MM482 & 135 & SHIV-MK1 & $<100$ & $26029(4605)$ & $345(82)$ & $104(22)$ \\
\hline MM498 & 103 & SHIV-MK1-1stPS & $<100$ & $8773(1367)$ & $<100$ & $<100$ \\
\hline MM504 & 103 & SHIV-MK1-2ndPS & $<100$ & $4966(547)$ & $<100$ & $<100$ \\
\hline MM481 & 61 & & $<100$ & $8208(1339)$ & $<100$ & $<100$ \\
\hline MM501 & 60 & \multirow{2}{*}{ SHIV-MK38 } & $<100$ & $4653(240)$ & $<100$ & $<100$ \\
MM502 & 61 & & $<100$ & $1454(232)$ & $<100$ & $<100$ \\
\hline MM597 & 60 & SHIV-MK38\#818 & $<100$ & $18626(2901)$ & $192(11)$ & $103(17)$ \\
\hline & HPP & & $<100$ & $17998(6205)$ & $358(92)$ & $273(81)$ \\
\hline
\end{tabular}

Range of $I D_{50}: \quad 100-119 \quad 120-999 \quad \geqq 1000$

$<100$ : under 100 times dilution

N.D. : Not Done

HPP : Human Pool Plasma

wpi : Weeks Post Infection

( ) : Standard Deviation

Table 5 Neutralization activity and breadth against heterologous viruses over time

\section{A. MM482: Infected with MK1}

\begin{tabular}{|c|c|c|c|c|c|c|c|c|c|c|c|c|c|}
\hline \multirow{2}{*}{$\begin{array}{c}\text { weeks post } \\
\text { inoculaton }\end{array}$} & MLV & SF162 & 6535 & SC422661 & REJO4541 & QH0692 & RHPA4259 & WITO4160 & TRO & CAAN5342 & AC10 & TRJO4551 & PVO \\
\hline & control & Tier1A & Tier1B & \multicolumn{7}{|c|}{ Tier2 } & \multicolumn{3}{|c|}{ Tier3 } \\
\hline \hline pre & $<100$ & $<100$ & $<100$ & $<100$ & $<100$ & $<100$ & $<100$ & $<100$ & $<100$ & $<100$ & $<100$ & $<100$ & $<100$ \\
\hline 6 & N.D. & $755(79)$ & N.D. & N.D. & N.D. & N.D. & N.D. & N.D. & N.D. & N.D. & N.D. & N.D. & N.D. \\
\hline 12 & N.D. & $3096(245)$ & N.D. & N.D. & N.D. & N.D. & N.D. & N.D. & N.D. & N.D. & N.D. & N.D. & N.D. \\
\hline 36 & N.D. & $11814(3103)$ & $<100$ & $<100$ & $<100$ & $<100$ & $<100$ & $<100$ & $<100$ & $<100$ & $<100$ & $<100$ & $<100$ \\
\hline 46 & N.D. & $15244(4071)$ & N.D. & N.D. & N.D. & N.D. & N.D. & N.D. & N.D. & N.D. & N.D. & N.D. & N.D. \\
\hline 64 & N.D. & $28968(5857)$ & $145(23)$ & $<100$ & $<100$ & $<100$ & $<100$ & $<100$ & $<100$ & $<100$ & $<100$ & $<100$ & $<100$ \\
\hline 81 & N.D. & $34123(6610)$ & $142(14)$ & $111(10)$ & $<100$ & N.D. & $<100$ & $<100$ & $<100$ & $<100$ & $<100$ & $<100$ & $<100$ \\
\hline 101 & N.D. & $39033(6705)$ & $341(33)$ & $126(17)$ & $109(20)$ & $107(75)$ & $596(44)$ & $<100$ & $<100$ & $<100$ & $<100$ & $<100$ & $<100$ \\
\hline 135 & $<100$ & $26029(4605)$ & $345(82)$ & $<100$ & $104(22)$ & $123(46)$ & $500(84)$ & $<100$ & $<100$ & $<100$ & $<100$ & $<100$ & $<100$ \\
\hline HPP & $<100$ & $17998(6205)$ & $358(92)$ & $298(49)$ & $273(81)$ & $275(48)$ & $257(48)$ & $146(39)$ & $291(66)$ & $149(28)$ & $116(31)$ & $202(98)$ & $163(83)$ \\
\hline
\end{tabular}

\section{B. MM597: Infected with \#818}

\begin{tabular}{|c|c|c|c|c|c|c|c|c|c|c|c|c|c|}
\hline \multirow{2}{*}{$\begin{array}{l}\text { weeks post } \\
\text { inoculaton }\end{array}$} & \multirow{2}{*}{$\frac{\mathrm{MLV}}{\text { control }}$} & \multirow{2}{*}{$\begin{array}{l}\text { SF162 } \\
\text { Tier1A }\end{array}$} & \multirow{2}{*}{$\begin{array}{l}6535 \\
\text { Tier1B }\end{array}$} & SC422661 & REJO4541 & $\mathrm{QH} 0692$ & RHPA4259 & WITO4160 & TRO & CAAN5342 & $\mathrm{AC} 10$ & TRJO4551 & PVO \\
\hline & & & & \multicolumn{8}{|c|}{ Tier2 } & \multicolumn{2}{|c|}{ Tier3 } \\
\hline pre & $<100$ & $<100$ & $<100$ & $<100$ & $<100$ & $<100$ & $<100$ & $<100$ & $<100$ & $<100$ & $<100$ & $<100$ & $<100$ \\
\hline 6 & N.D. & $300(68)$ & N.D. & N.D. & N.D. & N.D. & N.D. & N.D. & N.D. & N.D. & N.D. & N.D. & N.D. \\
\hline 12 & N.D. & $957(89)$ & N.D. & N.D. & N.D. & N.D. & N.D. & N.D. & N.D. & N.D. & N.D. & N.D. & N.D. \\
\hline 28 & N.D. & $5131(1450)$ & $<100$ & $112(28)$ & $<100$ & $<100$ & $<100$ & $<100$ & $<100$ & $<100$ & $<100$ & $<100$ & $<100$ \\
\hline 41 & N.D. & 11029 (3464) & $<100$ & $<100$ & $<100$ & $<100$ & $<100$ & $<100$ & $<100$ & $<100$ & $<100$ & $<100$ & $<100$ \\
\hline 51 & N.D. & 17189 (4198) & N.D. & N.D. & N.D. & N.D. & N.D. & N.D. & N.D. & N.D. & N.D. & N.D. & N.D. \\
\hline 60 & $<100$ & $18626(2901)$ & $192(11)$ & $105(17)$ & $103(17)$ & $<100$ & $113(44)$ & $<100$ & $<100$ & $<100$ & $<100$ & $<100$ & $<100$ \\
\hline HPP & $<100$ & 17998 (6205) & 358 (92) & $298(49)$ & $273(81)$ & $275(48)$ & $257(48)$ & $146(39)$ & $291(66)$ & $149(28)$ & $116(31)$ & $202(98)$ & $163(83)$ \\
\hline
\end{tabular}

\footnotetext{
Range of $\mathrm{ID}_{50}: \quad 100-119 \quad 120-999$

$<100$ : under 100 times dilution

N.D. : Not Done

HPP : Human Pool Plasma

wpi : Weeks Post Infection

( ) : Standard Deviation
}

against 6535 was 145 at 64 wpi, that against SC422661 was 111 at 81 wpi and 126 at 101 wpi, that against RHPA4259 was 596 at 101 wpi, that against QH0692 was 107 at 101 wpi and 123 at 135 wpi, and that against REJO4541 was 109 at $101 \mathrm{wpi}$ and 104 at $135 \mathrm{wpi}$. At 101 and $135 \mathrm{wpi}$, two of the tier 2 panel viruses were neutralized (Table 5A and Fig. 1). 


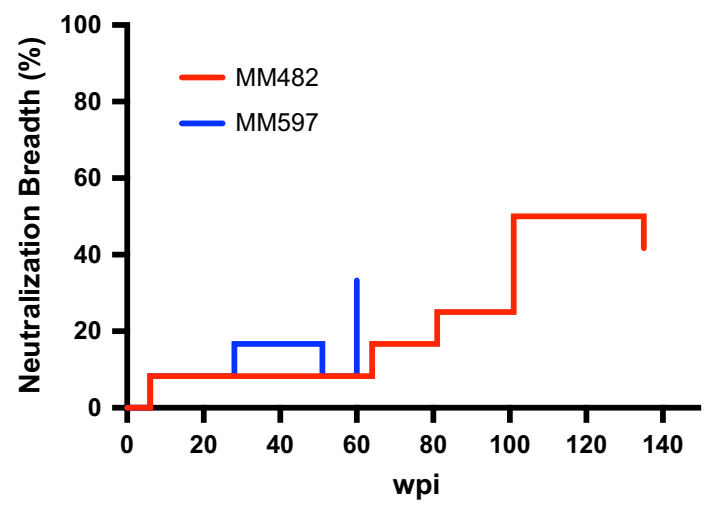

Fig. 1 Breadth of neutralization activity in MM482 (red) and MM597 (blue). Changes in neutralization breadth against all heterologous pseudotype viruses are shown

In MM597, the $\mathrm{ID}_{50}$ value against SC422661 was 112 at 28 wpi and 105 at 60 wpi. In MM597, the ID $_{50}$ values against 6535, REJO4541, and RHPA4259 at 60 wpi were 192, 103, and 113, respectively (Table 5B and Fig. 1). The neutralization activity of plasma from MM597 against tier 2 viruses at 60 wpi was less than that of plasma from MM482 after 101 wpi. Therefore, nAbs against heterologous tier 2 virus are induced by infection with tier $1 \mathrm{~B}$ virus after $101 \mathrm{wpi}$. It is also possible that nAbs against heterologous tier 2 viruses begin to be induced after infection with tier 2 virus. These findings suggest that antibody maturation broadens the neutralizing activity over time.

\section{Change from tier $1 \mathrm{~B}$ to tier 2 virus in an MK1-infected macaque}

In the body of HIV-1-infected patients, neutralizing antibodies evolve as the virus mutates [34]. Therefore, neutralizing antibodies may be produced as a tier 1B virus changes to a tier 2 virus in macaques. To confirm this, we analyzed viral resistance to neutralization over time in MM482, which had the highest and broadest neutralization activity. Pseudoviruses with the env gene were collected from plasma during each week of infection and evaluated for neutralization resistance using KD247, \#818 (tier 2 virus), and MK 1 (tier 1 $B$ virus). The GPGR epitope of KD 247 was preserved in all viruses from 5 to 115 wpi in the plasma of MM482. Clones $3,4,5,6,8,9$, and 10 were prepared from 12 wpi plasma. Clones 6 and 10 contained minor amino acid mutations. All of the clones showed greater resistance to neutralization than the tier $1 \mathrm{~B}$ MK 1 virus, but less resistance than that of the tier $2 \# 818$ virus. At 12 wpi, all clones $(3,4,5,6,8,9$, and 10) remained tier 1B (Fig. 2A). Clones 2, 3, 5, 7, and 8 were prepared from 36 wpi plasma and contained minor amino acid mutations. Because clone 7 was more susceptible to neutralization than tier 1B MK 1, it was determined to be a tier $1 \mathrm{~A}$ virus, and because clone 8 was between MK 1 and \#818, it was determined to be a tier $1 \mathrm{~B}$ virus. Because clones 2,3 , and 5 showed neutralization resistance similar to that of \#818, they were determined to be tier 2 viruses (Fig. 2B). Three of five clones were of tier 2 at 36 wpi. Eight, nine and ten clones were prepared from plasma obtained at 46, 70 and 104 wpi, respectively. The neutralization resistance of clones with minor mutations, and of those with consensus sequences, was next evaluated. At 46, 70, and 104 wpi, all clones showed neutralization resistance equivalent to that of \#818 and were thus determined to be tier 2 viruses (Fig. 2C, $\mathrm{D}$, and $\mathrm{E})$. These results suggest that tier 2 virus appeared at $36 \mathrm{wpi}$, and further that only tier 2 viruses proliferated after 46 wpi in MM482, which was infected with tier 1B MK1.

\section{Mutations related to neutralization resistance and induction of broadly neutralizing antibodies}

To identify mutations related to neutralization resistance and induction of broadly neutralizing antibodies, a mutation analysis of $e n v$ was performed. Direct sequencing showed a consensus sequence lacking minor mutations (Fig. 3). The minor mutations detected in the neutralization-susceptible clones 7 and 8 at 36 wpi were not included. First, common mutations were found from 36 wpi (when neutralizationresistant tier 2 virus appeared) to 115 wpi. These comprised N169D, K187E, S190N in the V2 region, S239 in the C2 region, $\mathrm{T} 459 \mathrm{~N}$ in the $\mathrm{V} 5$ region $(\mathrm{T} 459 \mathrm{D}$ at $91 \mathrm{wpi}$ ), and V842A in the cytoplasmic tail (Fig. 3, red font). S190N and T459N gained more potential N-linked glycosylation sites compared to MK1. Next, common mutations were found from 91 to $115 \mathrm{wpi}$; the former was the timepoint at which the maximum neutralizing activity against heterologous viruses was detected. We found the mutations S145N and G149E in the V1 region, D279N in the C2 region, S311P in the $\mathrm{V} 3$ region, and $\mathrm{I} 347 \mathrm{~V}$ and $\mathrm{I} 372 \mathrm{~V}$ in the $\mathrm{C} 3$ region (Fig. 3, blue font). S145N and D279N gained potential N-linked glycosylation sites compared to MK1. These findings imply that these mutations are related to neutralization resistance and induction of broadly neutralizing antibodies.

\section{Discussion}

The SHIV strains MK1, MK38, and \#818, which were derived from SHIV-89.6, are CCR5-tropic and have different levels of resistance to neutralization (tier 1B and 2) [51, 52]. These viruses are genetically similar to SHIV-89.6 $P$ [50], which is widely used in vaccine development. In this study, we developed a rhesus macaque model of induction of anti-HIV-1 nAbs.

In MM597, nAbs against parental-lineage tier 2 viruses were rapidly induced, and nAbs against heterologous tier 

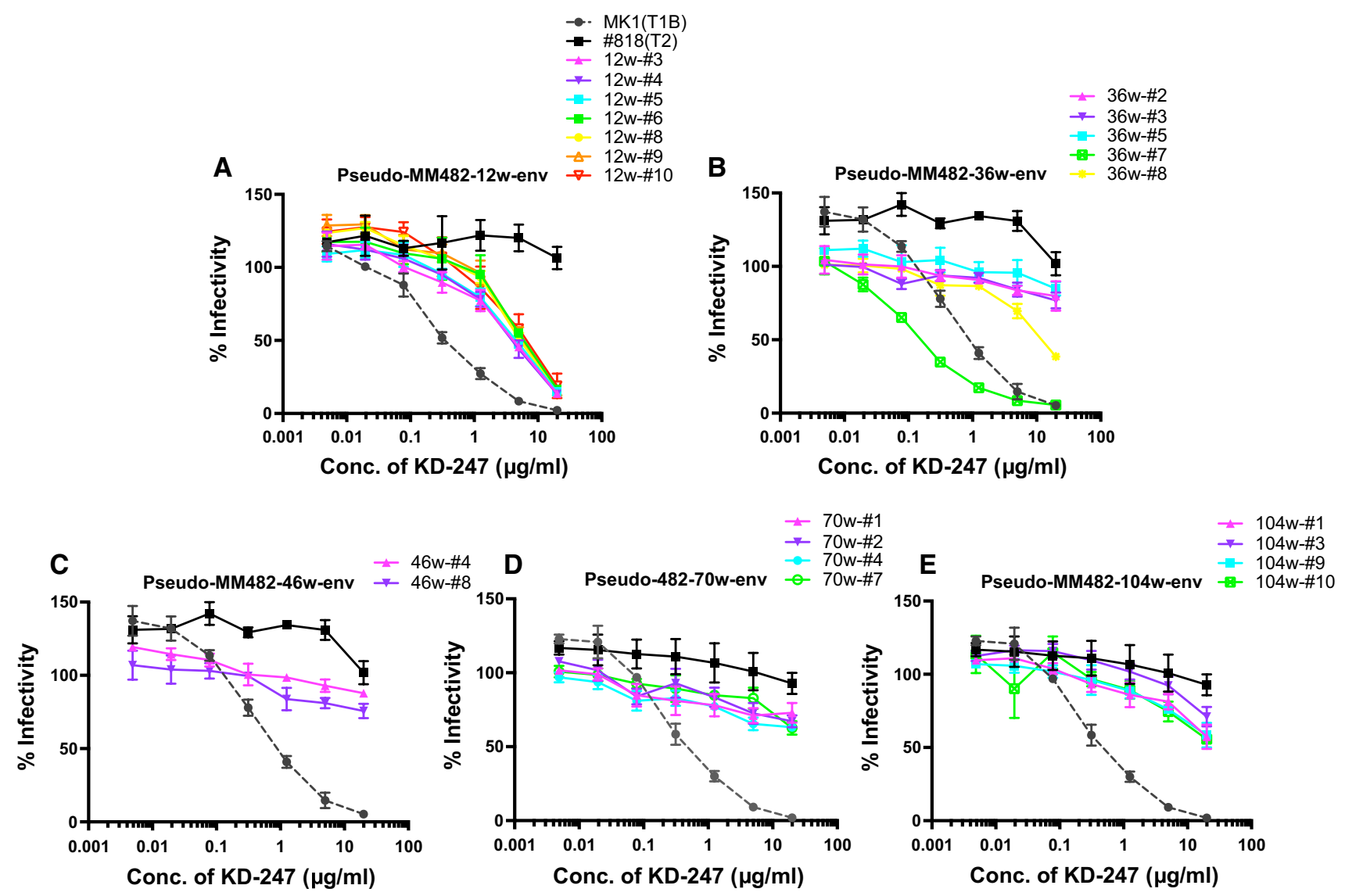

Fig. 2 Analysis of the neutralization resistance of pseudotype viruses to HIV-1-neutralizing antibodies (nAbs) against KD247. A, pseudoMM482-12wpi envelope. B, pseudo-MM482-36wpi envelope. C, pseudo-MM482-46wpi envelope. D, pseudo-MM482-70wpi enve-

lope. E, pseudo-MM482-104wpi envelope. After pre-incubation with $100 \mathrm{TCID}_{50}$ of each virus and KD247, TZM-bl cells were cultured for $48 \mathrm{~h}$, and luciferase activity was measured. KD-247 was diluted fourfold from 20 to $0.005 \mu \mathrm{g} / \mathrm{mL}$

2 viruses were beginning to be induced (Tables 3 and 5; Fig. 1). In HIV-1-infected patients, self- or type-specific $\mathrm{Ab}$ responses develop first, followed by Abs with increased affinity and neutralization activity against autologous viruses [34]. Indeed, neutralization activity against parental-lineage virus increased in rhesus macaques infected with CCR5tropic SHIV. Moreover, in HIV-1-infected patients with nAbs against autologous virus, escape mutants are generated in the virus, and the env sequence diversity increases. Subsequently, the host humoral immune response results in production of nAbs with increased affinity. After a number of years, some patients produce antibodies that target one or more shared epitopes, resulting in cross-reactivity with heterologous strains. This leads to induction of broadly neutralizing antibodies with activity against diverse tier 2 viruses [34]. Therefore, \#818-infected rhesus macaques mimic $\mathrm{nAb}$ induction in HIV-1-infected patients and may be used to evaluate the induction of tier $2 \mathrm{nAbs}$.

KS661 was susceptible to neutralization (tier 1B). Induction of Abs in macaques infected with KS661 inhibits viral replication; however, MK38 became resistant to

neutralization (tier 2) [52]. MK38 and \#818 established persistent infections despite $\mathrm{nAb}$ production (Tables 2 and 4 ), possibly due to the emergence of neutralization-escape mutations or to resistance to nAbs due to the three-dimensional structure of the virus. Indeed, when the co-receptor changes from CXCR4 to CCR5, the resulting decrease in the net positive charge of $\mathrm{V} 3$ reduces its surface exposure, resulting in immunological escape from $n A b s[52,59]$.

In MM482, the N169D, K187E, S190N, S239, T459N (T459D at $91 \mathrm{wpi}$ ), and V842A mutations were detected at 36 wpi. Because the tier $2 \# 818$ virus has three mutations in the V2 region (N169D, K187E, and S190N) (Supplemental Figure), the above-mentioned six mutations likely contribute to neutralization resistance.

nAbs against tier 2 parental-lineage and heterologous viruses can be induced by infection with tier $1 \mathrm{~B}$ virus (Tables 2, 3, and 5; Fig. 1). In HIV-1-infected patients, neutralization results from viral mutations [34]. We analyzed viral resistance to neutralization over time in MM482. In MM482 infected with tier 1B MK 1 virus, the virus mutated from tier 1B to tier 2 at 36 wpi. In MM482, 


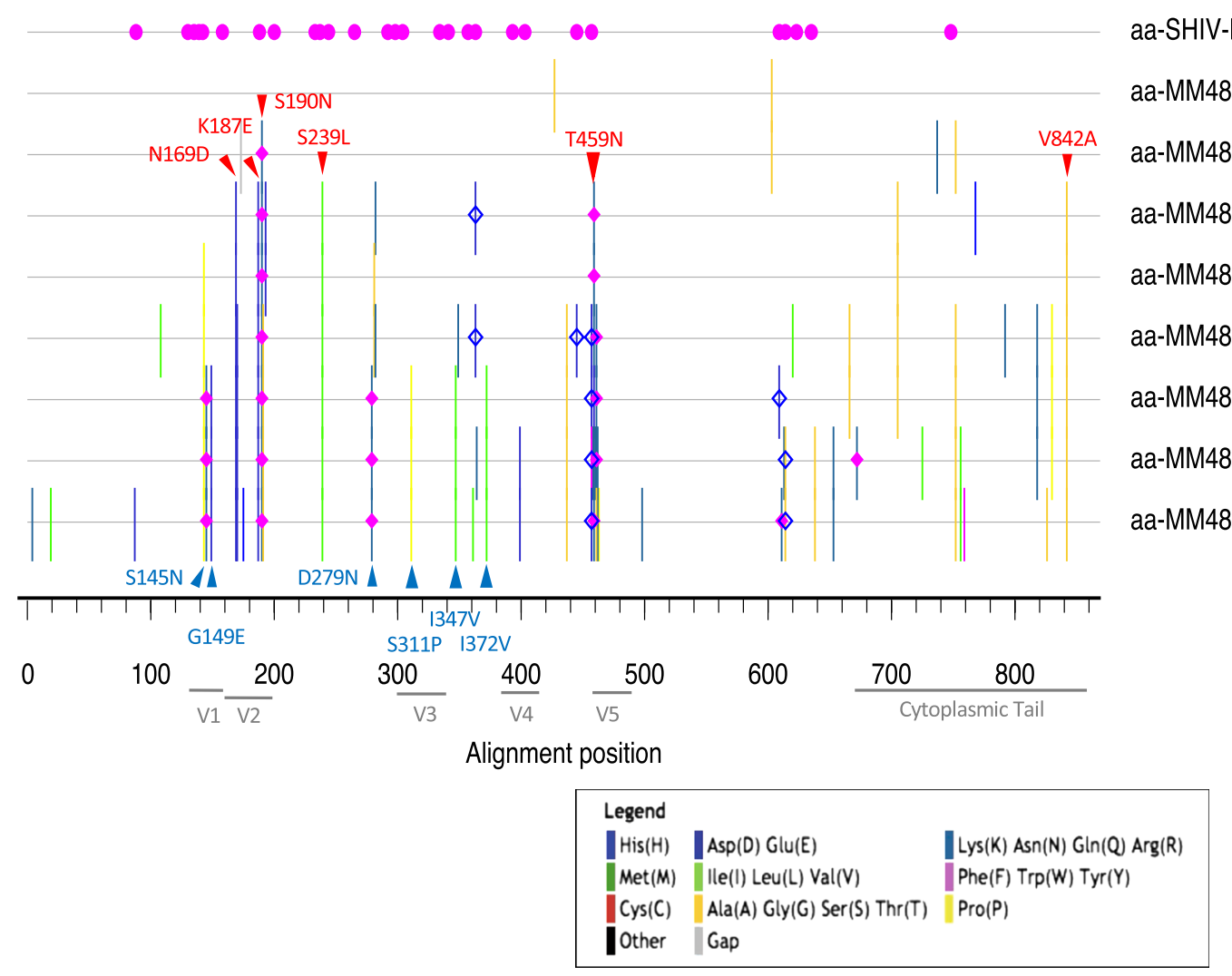

Fig. 3 Amino acid mutations post-inoculation in the plasma of MM482 infected with MK1. The original sequence is the SHIV-MK1 sequence. Pink circle, potential N-linked glycosylation site in the master. Pink diamond, potential $\mathrm{N}$-linked glycosylation sites gained in the query compared to the master. Blue open diamond, potential

nAbs against the tier $2 \# 818$ virus were detected at 64 wpi (Table 3A), and against two of the heterologous tier 2 viruses in the panel after 101 wpi (Table 5A). In MM597 infected with the tier $2 \# 818$ virus, nAbs against three strains of the heterologous tier 2 virus panel were beginning to be detected at $60 \mathrm{wpi}$, although their $\mathrm{ID}_{50}$ values were low (Table 5). These results imply that induction of broadly neutralizing antibodies occurs more than 60 weeks after infection with neutralization-resistant virus.

In MM482, the S145N, G149E, D279N, S311P, I347V and $\mathrm{I} 372 \mathrm{~V}$ mutations were detected from $91 \mathrm{wpi}$ to 115 wpi. Since the maximum neutralizing activity against heterologous viruses was detected at this time, six mutations may contribute to the induction of broadly neutralizing antibodies. Analysis of the epitopes targeted by the nAbs induced by MM482 is needed, together with verification that the mutations detected after $91 \mathrm{wpi}$ are important for induction of broadly neutralizing antibodies. It is possible that induction of broadly neutralizing antibodies can be accelerated by a viral antigen with mutations related to neutralization resistance and induction of broadly neutralizing antibodies.
$\mathrm{N}$-linked glycosylation sites lost in the query compared to the master. Red, common mutations after 36 wpi. Blue, common mutations from 91 to 115 wpi. Minor mutations in the consensus sequence are not shown

Based on our observations, \#818-infected rhesus macaques may be useful models for the induction of tier 2 nAbs. In addition, MK1 (tier 1B)-infected rhesus macaques will enable analysis of the neutralization resistance of viruses that induce tier $2 \mathrm{nAbs}$ and the antigen needed to induce broadly neutralizing antibodies. Finally, these animal models will facilitate the development of HIV-1 vaccines.

Acknowledgements We thank the NIH AIDS Reagent Program for providing a panel of reference subtype B env clones.

Funding This research was supported by Grants-in-Aid for Scientific Research (B) (Grant no. 16H04682) from the Japan Society for the Promotion of Science, and from the Japan Agency for Medical Research and Development (Grant nos. JP18fk0410011, JP18fk0410002, and JP18fk0410013).

\section{Compliance with ethical standards}

Conflict of interest The authors have no conflicts of interest to declare.

Ethical approval All animal studies were performed under anesthesia and adhered to protocols approved by the Committee for Experimental Use of Non-Human Primates of the Institute for Frontier Life and 
Medical Sciences, Kyoto University, Kyoto, Japan. Macaques were housed in a biosafety level 3 facility in which all of the procedures were performed.

Open Access This article is distributed under the terms of the Creative Commons Attribution 4.0 International License (http://creativecommons.org/licenses/by/4.0/), which permits unrestricted use, distribution, and reproduction in any medium, provided you give appropriate credit to the original author(s) and the source, provide a link to the Creative Commons license, and indicate if changes were made.

\section{References}

1. Chun TW, Finzi D, Margolick J, Chadwick K, Schwartz D, Siliciano RF (1995) In vivo fate of HIV-1-infected T cells: quantitative analysis of the transition to stable latency. Nat Med 1(12):1284-1290

2. Chun TW, Carruth L, Finzi D, Shen X, DiGiuseppe JA, Taylor H, Hermankova M, Chadwick K, Margolick J, Quinn TC, Kuo YH, Brookmeyer R, Zeiger MA, Barditch-Crovo P, Siliciano RF (1997) Quantification of latent tissue reservoirs and total body viral load in HIV-1 infection. Nature 387(6629):183-188. https ://doi.org/10.1038/387183a0

3. Chun TW, Stuyver L, Mizell SB, Ehler LA, Mican JA, Baseler M, Lloyd AL, Nowak MA, Fauci AS (1997) Presence of an inducible HIV-1 latent reservoir during highly active antiretroviral therapy. Proc Natl Acad Sci USA 94(24):13193-13197

4. Finzi D, Hermankova M, Pierson T, Carruth LM, Buck C, Chaisson RE, Quinn TC, Chadwick K, Margolick J, Brookmeyer R, Gallant J, Markowitz M, Ho DD, Richman DD, Siliciano RF (1997) Identification of a reservoir for HIV-1 in patients on highly active antiretroviral therapy. Science (New York, NY) 278(5341):1295-1300

5. Wong JK, Hezareh M, Gunthard HF, Havlir DV, Ignacio CC, Spina CA, Richman DD (1997) Recovery of replication-competent HIV despite prolonged suppression of plasma viremia. Science (New York, NY) 278(5341):1291-1295

6. Finzi D, Blankson J, Siliciano JD, Margolick JB, Chadwick K, Pierson T, Smith K, Lisziewicz J, Lori F, Flexner C, Quinn TC, Chaisson RE, Rosenberg E, Walker B, Gange S, Gallant J, Siliciano RF (1999) Latent infection of CD4+ T cells provides a mechanism for lifelong persistence of HIV-1, even in patients on effective combination therapy. Nat Med 5(5):512-517. https://doi. org/10.1038/8394

7. Siliciano JD, Kajdas J, Finzi D, Quinn TC, Chadwick K, Margolick JB, Kovacs C, Gange SJ, Siliciano RF (2003) Long-term follow-up studies confirm the stability of the latent reservoir for HIV-1 in resting CD4+ T cells. Nat Med 9(6):727-728. https:// doi.org/10.1038/nm880

8. Strain MC, Gunthard HF, Havlir DV, Ignacio CC, Smith DM, Leigh-Brown AJ, Macaranas TR, Lam RY, Daly OA, Fischer M, Opravil M, Levine H, Bacheler L, Spina CA, Richman DD, Wong JK (2003) Heterogeneous clearance rates of long-lived lymphocytes infected with HIV: intrinsic stability predicts lifelong persistence. Proc Natl Acad Sci USA 100(8):4819-4824. https://doi. org/10.1073/pnas.0736332100

9. Crooks AM, Bateson R, Cope AB, Dahl NP, Griggs MK, Kuruc JD, Gay CL, Eron JJ, Margolis DM, Bosch RJ, Archin NM (2015) Precise Quantitation of the Latent HIV-1 Reservoir: Implications for Eradication Strategies. J Infect Dis 212(9):1361-1365. https ://doi.org/10.1093/infdis/jiv218
10. Trkola A, Kuster H, Rusert P, Joos B, Fischer M, Leemann C, Manrique A, Huber M, Rehr M, Oxenius A, Weber R, Stiegler G, Vcelar B, Katinger H, Aceto L, Gunthard HF (2005) Delay of HIV-1 rebound after cessation of antiretroviral therapy through passive transfer of human neutralizing antibodies. Nat Med 11(6):615-622. https://doi.org/10.1038/nm1244

11. Klein F, Mouquet H, Dosenovic P, Scheid JF, Scharf L, Nussenzweig MC (2013) Antibodies in HIV-1 vaccine development and therapy. Science (New York, NY) 341(6151):1199-1204. https://doi.org/10.1126/science.1241144

12. Mascola JR, Haynes BF (2013) HIV-1 neutralizing antibodies: understanding nature's pathways. Immunol Rev 254(1):225244. https://doi.org/10.1111/imr.12075

13. Burton DR, Mascola JR (2015) Antibody responses to envelope glycoproteins in HIV-1 infection. Nat Immunol 16(6):571-576. https://doi.org/10.1038/ni.3158

14. Caskey M, Klein F, Lorenzi JC, Seaman MS, West AP Jr, Buckley N, Kremer G, Nogueira L, Braunschweig M, Scheid JF, Horwitz JA, Shimeliovich I, Ben-Avraham S, Witmer-Pack M, Platten M, Lehmann C, Burke LA, Hawthorne T, Gorelick RJ, Walker BD, Keler T, Gulick RM, Fatkenheuer G, Schlesinger SJ, Nussenzweig MC (2015) Viraemia suppressed in HIV1 -infected humans by broadly neutralizing antibody 3BNC117. Nature 522(7557):487-491. https://doi.org/10.1038/nature1441 1

15. Lynch RM, Boritz E, Coates EE, DeZure A, Madden P, Costner P, Enama ME, Plummer S, Holman L, Hendel CS, Gordon I, Casazza J, Conan-Cibotti M, Migueles SA, Tressler R, Bailer RT, McDermott A, Narpala S, O’Dell S, Wolf G, Lifson JD, Freemire BA, Gorelick RJ, Pandey JP, Mohan S, Chomont N, Fromentin R, Chun TW, Fauci AS, Schwartz RM, Koup RA, Douek DC, Hu Z, Capparelli E, Graham BS, Mascola JR, Ledgerwood JE (2015) Virologic effects of broadly neutralizing antibody VRC01 administration during chronic HIV-1 infection. Sci Transl Med 7(319):319ra206. https://doi.org/10.1126/scitranslmed.aad5752

16. Moore PL, Williamson C, Morris L (2015) Virological features associated with the development of broadly neutralizing antibodies to HIV-1. Trends Microbiol 23(4):204-211. https://doi. org/10.1016/j.tim.2014.12.007

17. Scheid JF, Horwitz JA, Bar-On Y, Kreider EF, Lu CL, Lorenzi JC, Feldmann A, Braunschweig M, Nogueira L, Oliveira T, Shimeliovich I, Patel R, Burke L, Cohen YZ, Hadrigan S, Settler A, Witmer-Pack M, West AP Jr, Juelg B, Keler T, Hawthorne T, Zingman B, Gulick RM, Pfeifer N, Learn GH, Seaman MS, Bjorkman PJ, Klein F, Schlesinger SJ, Walker BD, Hahn BH, Nussenzweig MC, Caskey M (2016) HIV-1 antibody 3BNC117 suppresses viral rebound in humans during treatment interruption. Nature 535(7613):556-560. https://doi.org/10.1038/nature18929

18. Simek MD, Rida W, Priddy FH, Pung P, Carrow E, Laufer DS, Lehrman JK, Boaz M, Tarragona-Fiol T, Miiro G, Birungi J, Pozniak A, McPhee DA, Manigart O, Karita E, Inwoley A, Jaoko W, Dehovitz J, Bekker LG, Pitisuttithum P, Paris R, Walker LM, Poignard P, Wrin T, Fast PE, Burton DR, Koff WC (2009) Human immunodeficiency virus type 1 elite neutralizers: individuals with broad and potent neutralizing activity identified by using a highthroughput neutralization assay together with an analytical selection algorithm. J Virol 83(14):7337-7348. https://doi.org/10.1128/ jvi.00110-09

19. Euler Z, van den Kerkhof TL, van Gils MJ, Burger JA, Edo-Matas D, Phung P, Wrin T, Schuitemaker H (2012) Longitudinal analysis of early HIV-1-specific neutralizing activity in an elite neutralizer and in five patients who developed cross-reactive neutralizing activity. J Virol 86(4):2045-2055. https://doi.org/10.1128/ jvi.06091-11

20. Trkola A, Dragic T, Arthos J, Binley JM, Olson WC, Allaway GP, Cheng-Mayer C, Robinson J, Maddon PJ, Moore JP (1996) 
CD4-dependent, antibody-sensitive interactions between HIV-1 and its co-receptor CCR-5. Nature 384(6605):184-187. https:// doi.org/10.1038/384184a0

21. Walker LM, Phogat SK, Chan-Hui PY, Wagner D, Phung P, Goss JL, Wrin T, Simek MD, Fling S, Mitcham JL, Lehrman JK, Priddy FH, Olsen OA, Frey SM, Hammond PW, Kaminsky S, Zamb T, Moyle M, Koff WC, Poignard P, Burton DR (2009) Broad and potent neutralizing antibodies from an African donor reveal a new HIV-1 vaccine target. Science (New York, NY) 326(5950):285289. https://doi.org/10.1126/science.1178746

22. Wu X, Yang ZY, Li Y, Hogerkorp CM, Schief WR, Seaman MS, Zhou T, Schmidt SD, Wu L, Xu L, Longo NS, McKee K, O’Dell S, Louder MK, Wycuff DL, Feng Y, Nason M, Doria-Rose N, Connors M, Kwong PD, Roederer M, Wyatt RT, Nabel GJ, Mascola JR (2010) Rational design of envelope identifies broadly neutralizing human monoclonal antibodies to HIV-1. Science (New York, NY) 329(5993):856-861. https://doi.org/10.1126/scien ce. 1187659

23. Walker LM, Huber M, Doores KJ, Falkowska E, Pejchal R, Julien JP, Wang SK, Ramos A, Chan-Hui PY, Moyle M, Mitcham JL, Hammond PW, Olsen OA, Phung P, Fling S, Wong CH, Phogat S, Wrin T, Simek MD, Protocol GPI, Koff WC, Wilson IA, Burton DR, Poignard P (2011) Broad neutralization coverage of HIV by multiple highly potent antibodies. Nature 477(7365):466-470. https://doi.org/10.1038/nature10373

24. Moldt B, Rakasz EG, Schultz N, Chan-Hui PY, Swiderek K, Weisgrau KL, Piaskowski SM, Bergman Z, Watkins DI, Poignard P, Burton DR (2012) Highly potent HIV-specific antibody neutralization in vitro translates into effective protection against mucosal SHIV challenge in vivo. Proc Natl Acad Sci US A 109(46):18921-18925. https://doi.org/10.1073/pnas.1214785109

25. Pegu A, Yang ZY, Boyington JC, Wu L, Ko SY, Schmidt SD, McKee K, Kong WP, Shi W, Chen X, Todd JP, Letvin NL, Huang J, Nason MC, Hoxie JA, Kwong PD, Connors M, Rao SS, Mascola JR, Nabel GJ (2014) Neutralizing antibodies to HIV-1 envelope protect more effectively in vivo than those to the $\mathrm{CD} 4$ receptor. Sci Transl Med 6(243):243ra288. https://doi.org/10.1126/scitr anslmed.3008992

26. Rudicell RS, Kwon YD, Ko SY, Pegu A, Louder MK, Georgiev IS, Wu X, Zhu J, Boyington JC, Chen X, Shi W, Yang ZY, DoriaRose NA, McKee K, O’Dell S, Schmidt SD, Chuang GY, Druz A, Soto C, Yang Y, Zhang B, Zhou T, Todd JP, Lloyd KE, Eudailey J, Roberts KE, Donald BR, Bailer RT, Ledgerwood J, Mullikin JC, Shapiro L, Koup RA, Graham BS, Nason MC, Connors M, Haynes BF, Rao SS, Roederer M, Kwong PD, Mascola JR, Nabel GJ (2014) Enhanced potency of a broadly neutralizing HIV-1 antibody in vitro improves protection against lentiviral infection in vivo. J Virol 88(21):12669-12682. https://doi.org/10.1128/ jvi.02213-14

27. Shingai M, Donau OK, Plishka RJ, Buckler-White A, Mascola JR, Nabel GJ, Nason MC, Montefiori D, Moldt B, Poignard P, Diskin R, Bjorkman PJ, Eckhaus MA, Klein F, Mouquet H, Cetrulo Lorenzi JC, Gazumyan A, Burton DR, Nussenzweig MC, Martin MA, Nishimura Y (2014) Passive transfer of modest titers of potent and broadly neutralizing anti-HIV monoclonal antibodies block SHIV infection in macaques. J Exp Med 211(10):2061-2074. https://doi. org/10.1084/jem.20132494

28. Saunders KO, Wang L, Joyce MG, Yang ZY, Balazs AB, Cheng C, Ko SY, Kong WP, Rudicell RS, Georgiev IS, Duan L, Foulds KE, Donaldson M, Xu L, Schmidt SD, Todd JP, Baltimore D, Roederer M, Haase AT, Kwong PD, Rao SS, Mascola JR, Nabel GJ (2015) Broadly Neutralizing Human Immunodeficiency Virus Type 1 Antibody Gene Transfer Protects Nonhuman Primates from Mucosal Simian-Human Immunodeficiency Virus Infection. J Virol 89(16):8334-8345. https://doi.org/10.1128/jvi.00908-15
29. Gautam R, Nishimura Y, Pegu A, Nason MC, Klein F, Gazumyan A, Golijanin J, Buckler-White A, Sadjadpour R, Wang K, Mankoff Z, Schmidt SD, Lifson JD, Mascola JR, Nussenzweig MC, Martin MA (2016) A single injection of anti-HIV-1 antibodies protects against repeated SHIV challenges. Nature 533(7601):105-109. https://doi.org/10.1038/nature17677

30. Moldt B, Le KM, Carnathan DG, Whitney JB, Schultz N, Lewis MG, Borducchi EN, Smith KM, Mackel JJ, Sweat SL, Hodges AP, Godzik A, Parren PW, Silvestri G, Barouch DH, Burton DR (2016) Neutralizing antibody affords comparable protection against vaginal and rectal simian/human immunodeficiency virus challenge in macaques. Aids 30(10):1543-1551. https:// doi.org/10.1097/qad.0000000000001102

31. Scheid JF, Mouquet H, Feldhahn N, Seaman MS, Velinzon K, Pietzsch J, Ott RG, Anthony RM, Zebroski H, Hurley A, Phogat A, Chakrabarti B, Li Y, Connors M, Pereyra F, Walker BD, Wardemann H, Ho D, Wyatt RT, Mascola JR, Ravetch JV, Nussenzweig MC (2009) Broad diversity of neutralizing antibodies isolated from memory B cells in HIV-infected individuals. Nature 458(7238):636-640. https://doi.org/10.1038/nature0793 0

32. Bhiman JN, Anthony C, Doria-Rose NA, Karimanzira O, Schramm CA, Khoza T, Kitchin D, Botha G, Gorman J, Garrett NJ, Abdool Karim SS, Shapiro L, Williamson C, Kwong PD, Mascola JR, Morris L, Moore PL (2015) Viral variants that initiate and drive maturation of V1V2-directed HIV-1 broadly neutralizing antibodies. Nat Med 21(11):1332-1336. https://doi.org/10.1038/ nm.3963

33. Francica JR, Sheng Z, Zhang Z, Nishimura Y, Shingai M, Ramesh A, Keele BF, Schmidt SD, Flynn BJ, Darko S, Lynch RM, Yamamoto T, Matus-Nicodemos R, Wolinsky D, Nason M, Valiante NM, Malyala P, De Gregorio E, Barnett SW, Singh M, O'Hagan DT, Koup RA, Mascola JR, Martin MA, Kepler TB, Douek DC, Shapiro L, Seder RA (2015) Analysis of immunoglobulin transcripts and hypermutation following SHIV(AD8) infection and protein-plus-adjuvant immunization. Nat Commun 6:6565. https ://doi.org/10.1038/ncomms7565

34. Pegu A, Hessell AJ, Mascola JR, Haigwood NL (2017) Use of broadly neutralizing antibodies for HIV-1 prevention. Immunol Rev 275(1):296-312. https://doi.org/10.1111/imr.12511

35. Yuste E, Johnson W, Pavlakis GN, Desrosiers RC (2005) Virion envelope content, infectivity, and neutralization sensitivity of simian immunodeficiency virus. J Virol 79(19):12455-12463. https ://doi.org/10.1128/jvi.79.19.12455-12463.2005

36. Javaherian K, Langlois AJ, Schmidt S, Kaufmann M, Cates N, Langedijk JP, Meloen RH, Desrosiers RC, Burns DP, Bolognesi DP et al (1992) The principal neutralization determinant of simian immunodeficiency virus differs from that of human immunodeficiency virus type 1. Proc Natl Acad Sci USA 89(4):1418-1422

37. Shibata R, Kawamura M, Sakai H, Hayami M, Ishimoto A, Adachi A (1991) Generation of a chimeric human and simian immunodeficiency virus infectious to monkey peripheral blood mononuclear cells. J Virol 65(7):3514-3520

38. Watkins DI, Burton DR, Kallas EG, Moore JP, Koff WC (2008) Nonhuman primate models and the failure of the Merck HIV-1 vaccine in humans. Nat Med 14(6):617-621. https://doi. org/10.1038/nm.f.1759

39. Seaman MS, Janes H, Hawkins N, Grandpre LE, Devoy C, Giri A, Coffey RT, Harris L, Wood B, Daniels MG, Bhattacharya T, Lapedes A, Polonis VR, McCutchan FE, Gilbert PB, Self SG, Korber BT, Montefiori DC, Mascola JR (2010) Tiered categorization of a diverse panel of HIV-1 Env pseudoviruses for assessment of neutralizing antibodies. J Virol 84(3):1439-1452. https://doi. org/10.1128/jvi.02108-09

40. Inaba K, Fukazawa $\mathrm{Y}$, Matsuda K, Himeno A, Matsuyama M, Ibuki K, Miura Y, Koyanagi Y, Nakajima A, Blumberg RS, 
Takahashi H, Hayami M, Igarashi T, Miura T (2010) Small intestine CD4+ cell reduction and enteropathy in simian/human immunodeficiency virus KS661-infected rhesus macaques in the presence of low viral load. J Gen Virol 91(Pt 3):773-781. https:// doi.org/10.1099/vir.0.017368-0

41. Harouse JM, Gettie A, Tan RC, Blanchard J, Cheng-Mayer C (1999) Distinct pathogenic sequela in rhesus macaques infected with CCR5 or CXCR4 utilizing SHIVs. Science (New York, NY) 284(5415):816-819

42. Harouse JM, Gettie A, Eshetu T, Tan RC, Bohm R, Blanchard J, Baskin G, Cheng-Mayer C (2001) Mucosal transmission and induction of simian AIDS by CCR5-specific simian/human immunodeficiency virus SHIV(SF162P3). J Virol 75(4):1990-1995. https://doi.org/10.1128/jvi.75.4.1990-1995.2001

43. Nishimura Y, Shingai M, Willey R, Sadjadpour R, Lee WR, Brown CR, Brenchley JM, Buckler-White A, Petros R, Eckhaus M, Hoffman V, Igarashi T, Martin MA (2010) Generation of the pathogenic R5-tropic simian/human immunodeficiency virus SHIVAD8 by Serial passaging in rhesus macaques. J Virol 84(9):4769-4781. https://doi.org/10.1128/jvi.02279-09

44. Gautam R, Nishimura Y, Lee WR, Donau O, Buckler-White A, Shingai M, Sadjadpour R, Schmidt SD, LaBranche CC, Keele BF, Montefiori D, Mascola JR, Martin MA (2012) Pathogenicity and mucosal transmissibility of the R5-tropic simian/human immunodeficiency virus SHIVAD8 in rhesus macaques: implications for use in vaccine studies. J Virol 86(16):8516-8526. https://doi. org/10.1128/jvi.00644-12

45. Shingai M, Donau OK, Schmidt SD, Gautam R, Plishka RJ, Buckler-White A, Sadjadpour R, Lee WR, LaBranche CC, Montefiori DC, Mascola JR, Nishimura Y, Martin MA (2012) Most rhesus macaques infected with the CCR5-tropic SHIV(AD8) generate cross-reactive antibodies that neutralize multiple HIV-1 strains. Proc Natl Acad Sci USA 109(48):19769-19774. https://doi. org/10.1073/pnas.1217443109

46. Gardner MR, Kattenhorn LM, Kondur HR, von Schaewen M, Dorfman T, Chiang JJ, Haworth KG, Decker JM, Alpert MD, Bailey CC, Neale ES Jr, Fellinger CH, Joshi VR, Fuchs SP, MartinezNavio JM, Quinlan BD, Yao AY, Mouquet H, Gorman J, Zhang B, Poignard P, Nussenzweig MC, Burton DR, Kwong PD, Piatak M Jr, Lifson JD, Gao G, Desrosiers RC, Evans DT, Hahn BH, Ploss A, Cannon PM, Seaman MS, Farzan M (2015) AAV-expressed eCD4-Ig provides durable protection from multiple SHIV challenges. Nature 519(7541):87-91. https://doi.org/10.1038/natur e14264

47. Barouch DH, Santra S, Schmitz JE, Kuroda MJ, Fu TM, Wagner W, Bilska M, Craiu A, Zheng XX, Krivulka GR, Beaudry K, Lifton MA, Nickerson CE, Trigona WL, Punt K, Freed DC, Guan L, Dubey S, Casimiro D, Simon A, Davies ME, Chastain M, Strom TB, Gelman RS, Montefiori DC, Lewis MG, Emini EA, Shiver JW, Letvin NL (2000) Control of viremia and prevention of clinical AIDS in rhesus monkeys by cytokine-augmented DNA vaccination. Science (New York, NY) 290(5491):486-492

48. Amara RR, Villinger F, Altman JD, Lydy SL, O'Neil SP, Staprans SI, Montefiori DC, Xu Y, Herndon JG, Wyatt LS, Candido MA, Kozyr NL, Earl PL, Smith JM, Ma HL, Grimm BD, Hulsey ML, Miller J, McClure HM, McNicholl JM, Moss B, Robinson HL (2001) Control of a mucosal challenge and prevention of AIDS by a multiprotein DNA/MVA vaccine. Science (New York, NY) 292(5514):69-74

49. Rose NF, Marx PA, Luckay A, Nixon DF, Moretto WJ, Donahoe SM, Montefiori D, Roberts A, Buonocore L, Rose JK (2001) An effective AIDS vaccine based on live attenuated vesicular stomatitis virus recombinants. Cell 106(5):539-549

50. Shiver JW, Fu TM, Chen L, Casimiro DR, Davies ME, Evans RK, Zhang ZQ, Simon AJ, Trigona WL, Dubey SA, Huang L,
Harris VA, Long RS, Liang X, Handt L, Schleif WA, Zhu L, Freed DC, Persaud NV, Guan L, Punt KS, Tang A, Chen M, Wilson KA, Collins KB, Heidecker GJ, Fernandez VR, Perry HC, Joyce JG, Grimm KM, Cook JC, Keller PM, Kresock DS, Mach H, Troutman RD, Isopi LA, Williams DM, Xu Z, Bohannon KE, Volkin DB, Montefiori DC, Miura A, Krivulka GR, Lifton MA, Kuroda MJ, Schmitz JE, Letvin NL, Caulfield MJ, Bett AJ, Youil R, Kaslow DC, Emini EA (2002) Replication-incompetent adenoviral vaccine vector elicits effective anti-immunodeficiency-virus immunity. Nature 415(6869):331-335. https://doi. org/10.1038/415331a

51. Matsuda K, Inaba K, Fukazawa Y, Matsuyama M, Ibuki K, Horiike M, Saito N, Hayami M, Igarashi T, Miura T (2010) In vivo analysis of a new R5 tropic SHIV generated from the highly pathogenic SHIV-KS661, a derivative of SHIV-89.6. Virology 399(1):134-143. https://doi.org/10.1016/j.virol.2010.01.008

52. Ishida $Y$, Kato F, Hishiki T, Matsuura K, Miura T, Watanabe Y, Yoneda M, Igarashi T, Matsushita S, Kikukawa M, Otsuki H (2016) Generation of a neutralization-resistant CCR5 tropic simian/human immunodeficiency virus (SHIV-MK38) molecular clone, a derivative of SHIV-89.6. J Gen Virol 97(5):1249-1260. https://doi.org/10.1099/jgv.0.000421

53. Cardozo T, Kimura T, Philpott S, Weiser B, Burger H, ZollaPazner S (2007) Structural basis for coreceptor selectivity by the HIV type 1 V3 loop. AIDS Res Hum Retroviruses 23(3):415-426. https://doi.org/10.1089/aid.2006.0130

54. Yamaguchi-Kabata Y, Yamashita M, Ohkura S, Hayami M, Miura $\mathrm{T}$ (2004) Linkage of amino acid variation and evolution of human immunodeficiency virus type 1 gp120 envelope glycoprotein (subtype B) with usage of the second receptor. J Mol Evol 58(3):333340. https://doi.org/10.1007/s00239-003-2555-x

55. Veazey RS, DeMaria M, Chalifoux LV, Shvetz DE, Pauley DR, Knight HL, Rosenzweig M, Johnson RP, Desrosiers RC, Lackner AA (1998) Gastrointestinal tract as a major site of CD4+ T cell depletion and viral replication in SIV infection. Science (New York, NY) 280(5362):427-431

56. Wang X, Rasmussen T, Pahar B, Poonia B, Alvarez X, Lackner AA, Veazey RS (2007) Massive infection and loss of CD4+ T cells occurs in the intestinal tract of neonatal rhesus macaques in acute SIV infection. Blood 109(3):1174-1181. https://doi. org/10.1182/blood-2006-04-015172

57. Otsuki H, Yoneda M, Igarashi T, Miura T (2014) Generation of a monkey-tropic human immunodeficiency virus type 1 carrying env from a CCR5-tropic subtype $\mathrm{C}$ clinical isolate. Virology 460-461:1-10. https://doi.org/10.1016/j.virol.2014.04.037

58. Wei X, Decker JM, Liu H, Zhang Z, Arani RB, Kilby JM, Saag MS, Wu X, Shaw GM, Kappes JC (2002) Emergence of resistant human immunodeficiency virus type 1 in patients receiving fusion inhibitor (T-20) monotherapy. Antimicrob Agents Chemother 46(6): 1896-1905

59. Naganawa $S$, Yokoyama M, Shiino T, Suzuki T, Ishigatsubo Y, Ueda A, Shirai A, Takeno M, Hayakawa S, Sato S, Tochikubo O, Kiyoura S, Sawada K, Ikegami T, Kanda T, Kitamura K, Sato H (2008) Net positive charge of HIV-1 CRF01_AE V3 sequence regulates viral sensitivity to humoral immunity. PLoS One 3(9):e3206. https://doi.org/10.1371/journal.pone.0003206

Publisher's Note Springer Nature remains neutral with regard to jurisdictional claims in published maps and institutional affiliations. 